\title{
Virtual Communities in an Online English Language Learning Forum
}

\author{
Farhana Diana Deris ${ }^{1}$, Rachel Tan Hooi Koon ${ }^{2} \&$ Abdul Rahim Salam ${ }^{1}$ \\ ${ }^{1}$ Language Academy, Universiti Teknologi Malaysia, Malaysia \\ ${ }^{2}$ INTI International College Subang (IICS), Kuala Lumpur, Malaysia \\ Correspondence: Farhana Diana Deris, D05, Language Academy, Universiti Teknologi Malaysia, 81310 UTM \\ Skudai, Johor Darul Takzim, Malaysia. Tel: 60-16-440-1630. E-mail: diana@utm.my
}

Received: November 7, 2014 Accepted: March 16, 2015 Online Published: June 28, 2015

doi:10.5539/ies.v8n13p79 URL: http://dx.doi.org/10.5539/ies.v8n13p79

\begin{abstract}
This study aims to shed light on the prospect of MyLinE (Malaysia Online Resources for Learning in English) as a platform for development of virtual communities of practice. Students discussion threads (DTs) in Lounge were explored to answer the following questions: (1) Are the discussion threads task-oriented? What are the tasks?; (2) What social structure patterns can be found from the discussion threads?; and (3) What are the shared resources that emerge from the interaction between participants? This study adopted a descriptive approach of document analysis whereby its main goal is to provide a detailed description of the patterns that emerged from the data. Specifically, interactional analysis was conducted to provide answers on the emergence of community. In addition, depth thread measure of 6-levels was also adopted to determine the quality of interaction. The findings of this study accentuated three features: (1) task-orientedness, (2) social structure patterns and (3) shared resources. Based on the interactional analysis done on DTs, six speech acts were also identified which indicated conversational exchanges between the participants. From the data, two types of discussion patterns were identified. The first was an intensive discussion that took place in a short period, and the second pattern identified was a discussion that stretched over a long period with long gaps between posts. From the data, participants were found to share three resources, which are (1) a shared idea of politeness, (2) a shared manner of expressing opinion and (3) shared manner of supporting opinion by using personal experience.
\end{abstract}

Keywords: virtual community, community of practice, online interactions

\section{Introduction}

Providing second language (L2) learners with a learning environment that could stimulate language learning and provide sufficient practice has been a matter of concern in the field of L2 acquisition. Inspired by this, Universiti Teknologi Malaysia (UTM) established MyLinE (Malaysia Online Resources for Learning in English) in 2007 for the use of students of all Malaysian public institutions of higher learning. By grounding its design and development on web-based learning theories, self-directed learning theories, social constructivist theories as well as sociocultural learning theories (SCT), MyLinE hopes to harness the dynamism of the Internet in order to afford learners with engaging, language-rich environment where learners can learn English and learn in English, and develop confidence in the process (Abdullah et al., 2013).

The Lounge, where the different types of forums converge (e.g. Students Guiding Students, Movie Reviews, Correct My English), forms the 'social' component of the learning portal that is underpinned by SCT. Among the notions related to this are socially-mediated learning in virtual communities and Wenger's 'Communities of Practice' (CoP) (Wenger et al., 2002). An online learning and sharing platform developed based on these notions seemed to offer great prospects and benefits. Virtual communities have been found to benefit learning such as enabling learning beyond the constraints of time and space of the classroom (Mason, 2011; Chang et al., 2008) and enabling knowledge construction (Palloff \& Pratt, 2007). In the context of language learning, virtual communities were found to encourage interaction and train discussion skills (Nunan, 2010), provide reading and writing practice (Raith, 2009), reduce anxiety of communication (Deris et al., 2012), as well as facilitate interaction and self-correction (Baten, et al., 2009).

Although virtual communities are beneficial for learning, studies have also reported difficulties in incorporating virtual communities in learning, especially when using asynchronous discussions (McKerlich et al., 2011; Traphagan et al., 2010; Hew et al., 2010; Deris, 2009; Hew \& Cheung, 2008). Common problems reported are 
withdrawal or fading back, non-sustained interaction (responses are similar to a question and answer session instead of a discussion), as well as non- or lack of participation (only one post is contributed when participation is compulsory).

To build virtual community, the following four steps are pertinent in ensuring its effectiveness: (1) defining the community's purpose, (2) setting up a gathering place, (3) promoting leadership and member roles, and (4) defining norms and conducts (Palloff \& Pratt, 2007). With the inception of Lounge, MyLinE has accomplished steps 1, 2 and 4. Nevertheless, as MyLinE is a self-access learning portal, leadership and member roles will have to be negotiated among the users of the forum themselves. Pallof and Pratt's (2007) idea of virtual community is similar to Wenger's (2006), who pointed out that "a virtual community or any traditional organization is the designed community". Virtual CoP, on the other hand, "is what emerges from the designed community".

Defining CoPs as "groups of people who share a concern or a passion for something they do and learn how to do it better as they interact regularly", Wenger (2006) presented a revised version of CoP as comprising three components, namely the domain, the community and the shared practice. Although many studies have used Wenger's description as framework (especially in face-to-face interactions), its criticisms that the description is too "fluid and can be very hard to grasp" and that the three domains may overlap with each other (Johnson, 2001) seem to apply in the case of this study. Due to this, Johnson's (2001) more organised version, which was developed based on analysis of case studies of CoP in the virtual context, was accepted.

Therefore, to build a virtual $\mathrm{CoP}$, the following four major components must exist: (1) task-oriented, (2) members, (3) social structure, and (4) shared resources. Following this framework, all CoPs are task-oriented and without a task, the CoP would not emerge. In this study, task is defined as the "use of the target language for a communicative purpose in order to achieve an outcome" and this "involves learners in comprehending, manipulating, producing or interacting in the TL in which the intention is to convey meaning rather than to manipulate the form" (Nunan, 2004). Meanwhile, concerning the remaining three components, members in the $\mathrm{CoP}$ should consist of expert and novice members, and the interaction that takes place between them is what builds the social structure. The sharing and negotiation of knowledge will occur as interaction takes place over time and from this interaction, shared resources would emerge.

Based on the distinction between virtual communities and virtual CoPs, the Lounge may form a virtual community of learners, but it may not be a CoP. As Wenger (2006) cautioned, "not everything called a community is a community of practice" and certainly, "a website in itself is not a community of practice". Therefore, after 7 years since its initiation, this study was conducted to investigate the development of virtual communities of practice in the Lounge in MyLinE. This study hoped to shed light on the prospect of the Lounge as a platform for development of CoP, from which language learners can share and learn from one another. Furthermore, the findings of this study could also help identify areas for improvement in the Lounge in order to achieve its goal of developing a community of self-directed learners. The following are the research questions that guided this study:

1) Are the started discussion threads task-oriented? What are the tasks?

2) What social structure patterns can be found from the discussion threads?

3) What are the shared resources that emerge from the interaction between participants?

\section{Method}

This study adopted a descriptive approach, whereby its main goal is to provide a "detailed description" (Cresswell, 2012) of the patterns that emerged from the data. As this is a small scale study, it utilized only document analysis as its instrument and therefore, the study did not attempt to explain or provide reasons for the description. However, in order to obtain reliable findings, the sample size (in this case the number of discussion threads analysed) was increased to ensure that the patterns are not singular occurring instances but consistent throughout the larger population.

Data for this study was obtained from the Student Forum in the Lounge which was made available for one full semester and has now been closed for new participation. Data from the current forum is not taken into account because new discussion threads or replies are still being added. In this forum, a total of 107 discussion threads (DTs) were identified and each of these threads had various 'life-spans', where the longest discussion thread lasted for 177 days while others did not receive any replies at all. All the threads were used as data for this study. Overall, there were a total of 1045 posts in the forum, contributed by a total of 935 participants. However, as this forum is based on voluntary participation, the number of contribution per participant varies with each individual. As shown in Table 1, the topics discussed in the forum could be grouped into four major categories: 
Table 1. Topic categories

\begin{tabular}{lll}
\hline No & Topic Category & Example \\
\hline 1 & Studies and academic matters & Memorize or Understanding? (DT21) \\
2 & Current student life in the university & Fashionista vs. Fashion Disaster in university (DT29) \\
3 & Post-university matters (career, etc.) & Career Research (DT42) \\
4 & General topics/general issues & Online Banking (DT27) \\
\hline
\end{tabular}

As for data analysis, a mix-method approach was used. Interactional analysis was conducted to provide answers for all three research questions. In line with Ellis and Barkhuizen's (2005, p. 176) assertion, this type of analysis is chosen because it allows researchers "to investigate a wide range of features of interaction, with each feature involving different categories and structures". This analysis is important since the emergence of CoP is dependent on the presence of interaction as "unless members interact and learn together, they do not form a community of practice" (Wenger, 2006). Based on the interactional analysis, the shared resources (language use, behaviour, etc.) that emerged were also determined.

To identify the social structure patterns, this study investigated two aspects; quality and duration of interaction, as quantity of posts might not indicate interaction. Therefore, to determine quality of interaction, this study adopted Hew and Cheung's (2008, p. 1114) depth thread measure of 6-levels because "such a level not only suggests that a discussion is taking place but also the possibility that the discussion is sustained or extended". Frequency counts were conducted to determine the percentage of DTs that have sustained interaction as well as to determine the duration of the interaction.

\section{Results and Discussion}

Findings of this study will be presented in the order of the three features of CoP: (1) task-orientedness, (2) social structure patterns and (3) shared resources.

\subsection{Task-Orientedness}

Six major communicative purposes were identified, which are (1) requesting for opinion, (2) requesting for information, (3) seeking for similar experiences, (4) identifying reasons, (5) asking for solutions, and (6) making comparisons, as illustrated in Table 2.

Table 2. Tasks identified in discussion threads

\begin{tabular}{|c|c|c|}
\hline No & $\begin{array}{l}\text { Communicative } \\
\text { Purpose (Task) }\end{array}$ & Examples \\
\hline 1 & $\begin{array}{l}\text { Requesting } \\
\text { opinion }\end{array}$ & $\begin{array}{l}\text { Many people believe that subjects such as music or sports are not useful. Thus } \\
\text { school should concentrate on subjects that offer better career prospect, what is your } \\
\text { opinion? (DT92) }\end{array}$ \\
\hline 2 & $\begin{array}{l}\text { Requesting } \\
\text { information }\end{array}$ & $\begin{array}{l}\text { I had registered for OSHA ( } 22 \text { Oct) and Quality Management (Dec). Does anyone } \\
\text { know what these courses are all about? (DT97) }\end{array}$ \\
\hline 3 & $\begin{array}{l}\text { Seeking for similar } \\
\text { experiences }\end{array}$ & $\begin{array}{l}\text { Let's share our experience about food you like and food you don't like. What do } \\
\text { you think of the price, etc. (DT78) }\end{array}$ \\
\hline 4 & Identifying reasons & $\begin{array}{l}\text { Do you agree with this statement? Why do you think varsity students are not on the } \\
\text { track of current issues? (DT95) }\end{array}$ \\
\hline 5 & $\begin{array}{l}\text { Asking } \\
\text { solutions }\end{array}$ & $\begin{array}{l}\text { Now } \mathrm{i} \text { was given a second chance \&i am leaving him for another person that } \mathrm{i} \text { feel } \\
\text { would be better than him. What should } \boldsymbol{i} \text { say to him? How am i going to tell him? } \\
\text { What will happen if i tell him?(DT17) }\end{array}$ \\
\hline 6 & $\begin{array}{l}\text { Making } \\
\text { comparisons }\end{array}$ & $\begin{array}{l}\text { "Hi, i have been given an offer from USM to take pharmacy and now i don't know } \mathrm{i} \\
\text { should take whether JPA local scholarship or PTPTN which one is better? And } \\
\text { actually i am not so aware of what both of them are giving.... Can anyone help } \\
\text { please? thank you:D" In your opinion, which is the best? (DT67) }\end{array}$ \\
\hline
\end{tabular}


Eighty-four DTs (78.5\%) were found to be task-oriented, with at least one communicative purpose identified. The role of talk "as an embodiment of social action" is imperative; it empowers people to "do things" and "perform actions" such as making requests, issuing invitation, etc (Atkinson, 2012; Ellis \& Barkhuizen, 2005). Therefore, the DT initiator may be making a request for participants to do something, for example, to discuss. The request was sometimes presented as questions, instructions, statements or a combination of more than one form (Table 3). As for the remaining DTs, no tasks were identified as participants were not requested to engage in any form of discussion.

Table 3. Task issued in the form of questions, instructions or statements

\begin{tabular}{lll}
\hline No & Task & Example \\
\hline 1 & Question & $\begin{array}{l}\text { so, what your opinion to this problem and what you can suggest to solve this problem? } \\
\text { (DT3) }\end{array}$ \\
2 & Instructions & $\begin{array}{l}\text { You can share your opinion here ;) (DT90) } \\
\text { Let's have lively and stimulating debate on this! (DT94) } \\
4\end{array}$ \\
\multirow{2}{*}{ Statements } & $\begin{array}{l}\text { i hope we can discuss more about this deep love meaning. (DT65) } \\
\text { so friend, } \boldsymbol{i} \text { would like to welcome all of you to share your opinion or any tips (...) (DT63) }\end{array}$ \\
\hline
\end{tabular}

\subsection{Social Structure Patterns: Sustained Interaction}

It was found from the measurement of depth thread that only $13.1 \%$ of DTs were at 6-level while another $9.4 \%$ were at 5-level, and this is consistent with the assertion that "the majority of the students' level of discussion tended to be low; i.e., the level of discussion was one (when person A posts a question and person B gives a reply)" (Hew \& Cheung, 2008). This type of discussion was more similar to a question and answer session consisting of a single response to a question, rather than an exchange of opinions about the issues at hand. On a different note, most DTs that are not task-oriented did not meet the 6-level depth except for three; DT20, DT42 and DT80.

Based on the interactional analysis done on DTs that met at least a 5-level depth measurement, six speech acts were identified which indicated conversational exchanges between the participants. They are 'agreeing/disagreeing by referring to specific posts by other participants', 'greeting', 'thanking', 'well-wishing', 'joking' and 'asking for agreements, opinions or confirmations'. Besides referring to each other's responses, 'greeting', 'thanking' and 'well-wishing' were also used and these are in fact common adjacency pairs found in conversations. 'Adjacency pairs' is an important feature in conversations that indicate interaction is taking place. An example of these adjacency pairs is presented in Table 4.

Table 4. Greeting, thanking and well-wishing (DT67)

\begin{tabular}{|c|c|}
\hline Student & Adjacency pairs \\
\hline KSY & $\begin{array}{l}\text { Glad to hear that you already accepted it. Don't you feel that it's hard to find jobs nowadays... All the } \\
\text { best }\end{array}$ \\
\hline SM & ...Tq KSY for your support. Wish you also good luck and all d best in UTM. \\
\hline KSY & All the best to you too! Strive for excellence and May God Bless you in everything you do! \\
\hline SM & $\begin{array}{l}\text { Good morning! KSY, thank } \boldsymbol{u} \text { vr much ya. I hope I can use JPA scholarship for the important thing in } \\
\text { UTM and help me to lighten the burden on my parent's shoulders. }\end{array}$ \\
\hline
\end{tabular}

\subsection{Social Structure Patterns: Duration of Interaction}

The duration of interaction was determined by calculating the number of days between the initial post and the last post in a discussion thread. Focusing only on DTs that have interaction of at least a 5-level depth, it was found that the longest duration was 177 days (DT3) while the shortest was 10 days (DT66). Although, it is suggested that the development of CoP requires "time and sustained interaction" and happens in stages (Wenger, 2006), the duration of interaction in order for CoP to emerge has not been determined. As these DTs comprised sustained interaction, the findings seemed to indicate that it may be possible for CoPs to develop even within as 
short a period as 10 days.

From the data, two types of discussion patterns were identified. The first was an intensive discussion that took place in a short period of time, for example in DT66. The concentration of posts on December 4th seemed to indicate that perhaps the interaction may have been somewhat synchronous, but the pace slowed down and then stopped altogether. The second pattern identified was a discussion that stretched over a long period of time with long gaps between posts, for example in DT17. The singular-post-per-day pattern seemed to show that while there was interaction taking place, it was very sparse and infrequent. As this is an asynchronous discussion, participants can take their time to respond to each others' post. However, studies cited in Hew, et al. (2010) have shown that the long wait between posts may reduce motivation in participation and cause withdrawal.

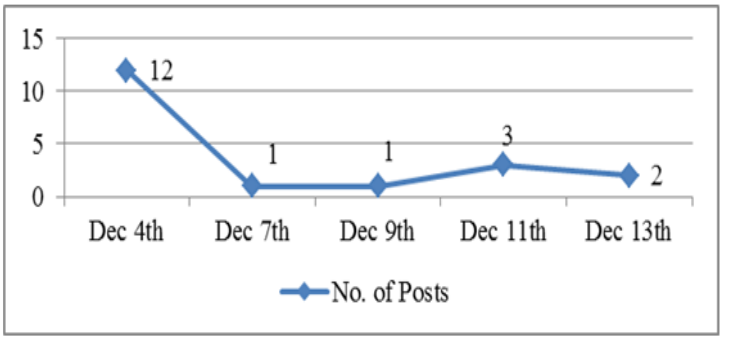

Figure 1. Discussion pattern for DT66

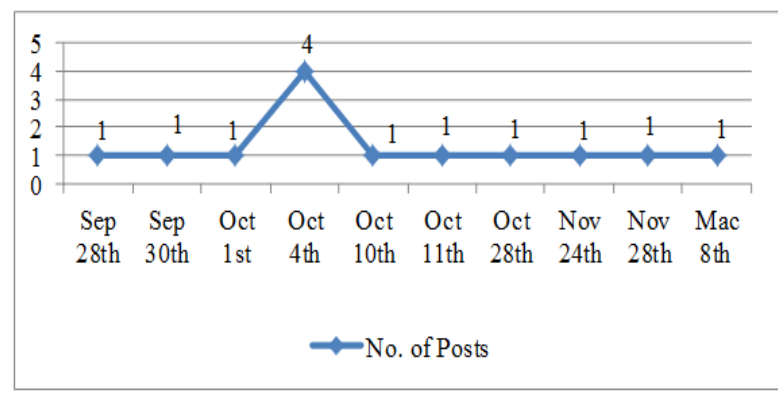

Figure 2. Discussion pattern for DT17

\subsection{Shared Resources: A Shared Idea of Politeness}

Politeness was a common norm in the forum and could have emerged from the participants' understanding and interpretation of the Lounge's guidelines for forum use, "You should not be rude". Table 5 presents examples of how politeness was practiced by the participants. While not all the participants displayed overt politeness forms, their interaction in general seemed congenial and non-threatening therefore direct disagreements were less used.

Table 5. Making polite requests

\begin{tabular}{lll}
\hline No & Task & Example \\
\hline 1 & Making polite requests & Please do share..., I hope..., I would like to... \\
2 & Greeting each other & hello there, hi, assalamualaikum \\
3 & Ending their post politely & thank you, tq, have a nice day \\
4 & Wishing each other well & good luck, god bless, all the best \\
5 & $\begin{array}{l}\text { Agreeing before } \\
\text { disagreeing }\end{array}$ & $\begin{array}{l}\text { I agree with you but, however, pardon me, depends on...but personally, } \\
\text { actually }\end{array}$ \\
\hline
\end{tabular}

In a study conducted by Borthick and Jones (2000), it was found that participants tended to agree and be positive with what everyone said because they did not know each other. Based on observation, in addition to adhering to the guidelines for forum use, the participants' polite behavior in the Lounge could be due to unfamiliarity with one another; this could be the reason they hardly sought for clarifications, used direct disagreements, and negotiated meaning. These acts require them to contradict each other at some point of time. No doubt, politeness is a good practice but over-politeness may cause unreal discussions, which could lead to difficulty participating in discussions outside the $\mathrm{L} 2$ learning classroom.

\subsection{Shared Resources: A Shared Manner of Expressing Opinion}

Besides being polite, it was also found that participants shared a similar manner of expressing opinion. Participants would usually start off by either agreeing or disagreeing with the initial or preceding post, followed by a reason for or elaboration of their stand. Then participants would provide evidence to support their reasoning, for example by drawing from personal experience, observations, and third-party experience or opinions. Occasionally, there would be requests for other opinions, advice-giving, or a word of encouragement. Some 
participants would start or end their post with greetings and thanks. Table 6 presents an example of such manner of expressing opinion. As highlighted in the earlier section, instances of politeness can also be seen in this example.

Table 6. Shared manner of expressing opinion (DT95)

\begin{tabular}{|c|c|}
\hline Student & Excerpt from DT95 \\
\hline DEK & $\begin{array}{l}\text { I agree with you. But when i looked this issue from different prespective. there are reason why } \\
\text { students nowadays refused to read about social issues, expecially on politics and racism.(...). So, it is } \\
\text { best for us not to trust news from these unreliable sources. } \\
\text { well,im not saying this as excuses to students who do not bother about what is happening in the } \\
\text { country,this is just a part of what i feel. well, i believe all of us (...).it is good for us to know about } \\
\text { current issues but beware of hating others when we become so engross in knowing social } \\
\text { issues,especially on politics... thank } \boldsymbol{u} \text { for reading. have a nice day and may god bless you all. }\end{array}$ \\
\hline $\mathrm{HCS}$ & $\begin{array}{l}\text { Thanks for the gist shared here. I do agree with your points that most politicians' statements really } \\
\text { puzzled people. I love reading newspaper a lot and follow up with social issues. Sometimes, I also } \\
\text { doubted the reliability of the news. Some of them just voicing up their words without much } \\
\text { consideration or just simply comment it for the sake of something. I believe they are quite a big } \\
\text { number of students who love and care about their beloved country.. The issue is that the country is still } \\
\text { not appropriate for you to criticize or comment freely. }\end{array}$ \\
\hline
\end{tabular}

\subsection{Shared Resources: A Shared Manner of Supporting Opinion by Using Personal Experience}

HCS's post is an example of using personal experience to support opinions. Other participants in the forum, as illustrated in Table 7 also use this step.

Table 7. Using personal experience to support opinion

\begin{tabular}{|c|c|c|}
\hline & Student & Excerpt from DTs \\
\hline \multirow[t]{2}{*}{ DT20 } & NABS & $\begin{array}{l}\text { I agree with SMA. For example, my class also have special group for us where we can do } \\
\text { group discussion and update latest information about class. (...) }\end{array}$ \\
\hline & GUAFM & $\begin{array}{l}\text { I am no doubt that facebook is helping us as stated by NABS because my class also have } \\
\text { special group for us so it easy for me as the class rep to tell or discuss something with my } \\
\text { classmates. But in my opinion as one of university student, facebook not very helpful in my } \\
\text { performance of study because when facebook I will be influenced by the games on } \\
\text { facebook. This will cause the time that should be used to do some revision or study has been } \\
\text { wasted just like that. For me, Google is helping my performance more. }\end{array}$ \\
\hline \multirow[t]{2}{*}{ DT94 } & KSY & $\begin{array}{l}\text { I agree with your statement that language is about practice, practice and practice! However it } \\
\text { depends on the surroundings. As an example, } \boldsymbol{i} \text { used to speak english during my primary } \\
\text { years because it is a SK school. However after entering secondary schools, i start to speak } \\
\text { mandarin more than English because majority of my Chinese friends there were chinese-ed. } \\
\text { (...) }\end{array}$ \\
\hline & ESY & $\begin{array}{l}\text { What happened to KSY occurs to me as well. From young, I prefer to talk to people around } \\
\text { me with English and even I went for } \operatorname{SJK}(\mathrm{C}) \text {, because of this I eventually neglected my } \\
\text { mother tongue. (...) }\end{array}$ \\
\hline
\end{tabular}

From the data, sharing of personal experiences seemed to help the participants, who may have never met each other face-to-face, relate to one another. Therefore, when participants discovered that they shared similar experience, interest, etc., interaction was sustained and CoPs may have emerged. Hence, these common practices that emerge from their interaction with each other may be considered as important to participants, and may even be a form of unspoken and unconscious rule that they abide to in their interaction as "their practices reflect the members' own understanding of what is important" (Johnson, 2001). 


\section{Conclusion}

This study started off with an aim to investigate the development of virtual CoPs in the Lounge of MyLinE from three aspects; task-orientedness, social structure patterns and shared resources. While the signs are encouraging, it can be concluded that the virtual CoPs in the Lounge are still in the development stage. At this point, the virtual communities act as a scaffold for language learning. In this sense, MyLinE has afforded L2 learners with a language-rich environment that could stimulate language learning and provide sufficient practice.

Overall, this study has provided important insights to the incorporation of virtual communities in a language learning portal. The most prominent observation is related to tasks. Findings from this research indicated that initial posts that do not specify a task for the participants to perform, usually do not take off as a discussion and will thus hinder the emergence of CoP. Lounge in the learning portal is a self-access forum; there may be no control over the tasks. However, in building virtual CoPs in a classroom, the teacher ought to specify a task for the learners to work on.

In addition, in this study, since participants' attention was on the tasks, their conversation exchanges suggested participants' focus more on getting their message across and not on language. Teachers should be aware that while the notion of $\mathrm{CoP}$ is beneficial for its socially-mediated learning, there may not be improvement in terms of quality of language use among the participants because language is of secondary concern to them. A common issue faced by teachers who implement task-based learning in the language classroom, teachers should not ignore it, but rather should emphasise the importance of instilling in the learners the awareness of how grammatical knowledge can express meaning (Nunan, 2004). Pedagogical approaches must be oriented towards fostering attention to form in context of real language use. When knowledge of language is being put into practice in language tasks delivered via interaction, interaction becomes a 'deep, holistic investment of learners' as active agents in language tasks (Atkinson, 2002, p. 536).

On that note, virtual CoPs such as in the Lounge may provide learners the opportunity to practice using the target language in meaning-oriented discussions. The asynchronous nature of forums provides learners the opportunity to practice communicating as in the real-world but in a less stressful environment. Ideally, their affective filter would be low and when coupled with being surrounded by people who share similar interest, learners could "learn how to do it [use of language] better as they interact regularly" (Wenger, 2006). Teachers must however be aware of and ready to manage the limitations in using asynchronous discussions. Otherwise, these limitations could cause frustration among the participants and consequently, perhaps even withdrawal. In the case of this study, virtual CoPs in the Lounge serve as a scaffold in the form of support group for learners where they motivate each other, or as a place for those in need of an environment to practice using the language with others of similar interest.

In terms of recommendations for further research, 'Membership' in the Lounge should be given attention. Studies could look into the participation of different roles (expert/novice) in the community and one possible direction is by using Knowlton's Taxonomy of Participating in Online Discussions (Wise et al., 2011). With passive participation at the lowest level of the taxonomy and meta-cognitive at the highest, it would be interesting to find out which level of participation are expert and novice members at. In addition, since this study has looked into a teacher-less learning environment, it will also be interesting to study virtual CoPs where learning experience is orchestrated by the language teacher. Finally, while politeness was found to be a shared practice among the participants, it could actually be a weakness of the asynchronous nature of the discussion. Hence, further studies could be conducted to determine the effects of this politeness syndrome on the participants' behavior in virtual CoPs as well as how politeness can be encouraged without going over-board.

\section{Acknowledgements}

We would like to thank the UTM MyLinE Administrators who granted us access to the learning portal for the purpose of collecting data for this study.

\section{References}

Abdullah, K. I., Puteh, F., Tan, H. K., Deris, F. D., Saidalvi, A., Mohd-Omar, N. A. (2013). Serendipity in MyLinE Forum. In Z. Zainal, \& T. Abdullah (Eds.), Ways of Language Learning. Malaysia: Penerbit UTM.

Atkinson, D. (2002). Towards a Sociocognitive Approach to Second Language Acquisition. The Modern Language Journal, 86, 525-545. http://dx.doi.org/10.1111/1540-4781.00159

Atkinson, D. (2012). Sociocognition: What It can Mean for Second Language Acquisition. In R. Batstone (Ed.), Sociocognitive Perspectives on Language Use and Language Learning (pp. 24-39). Oxford: Oxford University Press. 
Baten, L., Bouckaert, N., \& Kan, Y. (2009). The Use of Communities in a Virtual Learning Environment. In M. Thomas (Ed.), Handbook of Research on Web 2.0 and Second Language Learning (pp. 137-155). Hershey, PA: Information Science Reference. http://dx.doi.org/10.4018/978-1-60566-190-2.ch008

Chang, C. K., Chen, G. D., \& Li, L. Y. (2008). Constructing a community of practice to improve coursework activity. Computers and Education, 50(1), 235-247. http://dx.doi.org/10.1016/j.compedu.2006.05.003

Cresswell, J. W. (2012). Education research (4th ed.). Boston: Pearson.

Deris, F. D. (2009). Developing a Framework for Virtual Learning Environment to Enhance the Use of English (Unpublished master's thesis). Universiti Teknologi Malaysia, Malaysia.

Deris, F. D., Zakaria, M. H., Wan-Mansor, W. F. A., Saidalvi, A. (2012). Using VLE to Supplement English Language Proficiency Course. In W. F. A. Wan-Mansor (Ed.), Research in Online Language Teaching and Learning. Johor: Universiti Teknologi Malaysia Penerbit.

Ellis, R., \& Barkhuizen, G. (2005). Analysing Learner Language. Oxford: Oxford University Press.

Hew, K. F., \& Cheung, W. S. (2008). Attracting Student Participation in Asynchronous Online Discussions: A Case Study of Peer Facilitation. Computers and Education, 51, 1111-1124. http://dx.doi.org/10.1016/j.compedu.2007.11.002

Hew, K. F., Cheung, W. S., \& Ng, C. S. L. (2010). Student Contribution in Asynchronous Online Discussion: A Review of the Research and Empirical Exploration. Instructional Science, 38, 571-606. http://dx.doi.org/10.1007/s11251-008-9087-0

Johnson, C. M. (2001). A Survey on Current Research on Online Communities of Practice. The Internet and Higher Education, 4, 45-60. http://dx.doi.org/10.1016/S1096-7516(01)00047-1

Mason, A. (2011). Teaching Languages Online. Open Learning: The Journal of Open, Distance, and e-Learning, 26(3), 275-283.

McKerlich, R., Riis, M., Anderson, T., \& Eastman, B. (2011). Student Perceptions of Teaching Presence, Social Presence and Cognitive Presence in a Virtual World. MERLOT Journal of Online Learning and Teaching, 7(3), 324-336.

Nunan, D. (2004). Task-based Language Teaching. Cambridge: Cambridge University Press. http://dx.doi.org/10.1017/CBO9780511667336

Nunan, D. (2010). Technology Support for Second Language Learning. In P. Peterson, E. Baker, \& B. McGaw (Eds.), International Encyclopaedia of Education (3rd ed., pp. 204-210). Elsevier Ltd. http://dx.doi.org/10.1016/b978-0-08-044894-7.00730-2

Palloff, R. M., \& Pratt, K. (2007). Building Virtual Communities: Techniques that Work. Proceedings of the 23rd Annual Conference on Distance Teaching and Learning. Retrieved from http://www.uwex.edu/disted/conference/Resource_library/proceedings/07_5192.pdf

Raith, T. (2009). The Use of Weblogs in Language Education. In M. Thomas (Ed.), Handbook of Research on Web 2.0 and Second Language Learning (pp. 274-291). Hershey, PA: Information Science Reference. http://dx.doi.org/10.4018/978-1-60566-190-2.ch015

Traphagan, T. W., Chiang, Y.-h. V., Chang, H. M., Wattanawaha, B., Lee, H., Mayrath, M. C., . . Resta, P. E. (2010). Cognitive, Social \& Teaching Presence in a Virtual World and a Text Chat. Computers and Education, 55, 923-936. http://dx.doi.org/10.1016/j.compedu.2010.04.003

Wenger, E. (2006). Communities of Practice: A Brief Introduction. Retrieved April 6, 2012, from http://www.ewenger.com/theory/

Wenger, E., McDermott, R., \& Snyder, W. (2002). Cultivating Communities of Practice: A Guide to Managing Knowledge. Boston, MA: Harvard Business School Press.

Wise, A. F., Perera, N., Hsiao, Y. T., Speer, J., \& Marbouti, F. (2011). Microanalytic Case Study of Individual Participation Patterns in an Asynchronous Online Discussion in an Undergraduate Blended Course. Internet and Higher Education, 15, 108-117. http://dx.doi.org/10.1016/j.iheduc.2011.11.007 


\section{Copyrights}

Copyright for this article is retained by the author(s), with first publication rights granted to the journal.

This is an open-access article distributed under the terms and conditions of the Creative Commons Attribution license (http://creativecommons.org/licenses/by/3.0/). 